DOI https://doi.org/10.30970/2078-6999-2019-22-3

\title{
THE POLITICS OF REGRESSION: THE IDEA OF NATION STATE IN THE THOUGHT OF ERNST CASSIRER AND AUREL KOLNAI ${ }^{1}$
}

\author{
Andrzej Gniazdowski \\ Institute of Philosophy and Sociology Polish Academy of Sciences \\ agniazdo@ifispan.waw.pl
}

\begin{abstract}
The aim of this paper is to compare the approaches of Ernst Cassirer and Aurel Kolnai on the idea of the nation state in its most radical form, which consists of identifying national sovereignty with an unrestricted right of the nation to political, external, and internal self-determination. What the comparison attempted here focuses on, is the criticism on the conditions for the possibility of specific German nationalism, presented by Cassirer in his Myth of the State and by Kolnai in his War Against the West. According to the main thesis of this paper, insofar as both Cassirer and Kolnai recognized the role played in politics by emotions and considered political phenomena as being constituted by not only rational or at least calculable mechanisms, but also affective factors, like beliefs, religion, and myth, they tended to consider nationalism in terms of the politics of «regression,» understood, psychoanalytically, as a reversion of mental life, in some respects, to a former, or less developed, psychological state, characteristic of not only individual mental disorders, but also social psychosis.

It will be argued, that Cassirer and Kolnai, not unlike the representatives of the Frankfurt School, considered the contemporary preponderance of mythical thought in political philosophy to be an expression of the dialectic, which consisted in «relapsing» of the Enlightenment into mythology. As a main motive for the comparison of their political philosophies, an assumption will be presented in the paper, that, while taking into account the contemporary tendency to oppose national sovereignty to the sovereignty of international law, the approach to the idea of nation state, as presented by Cassirer and Kolnai, seems to be by no means out of date.

Key words: national state, regression, mythology, progress, political independence.
\end{abstract}

In this paper, I want to return to the political thought of Ernst Cassirer and Aurel Kolnai in order to reconstruct their approach to the idea of the nation state. What I particularly aim for is to compare their arguments against the idea of national sovereignty, understood as an unrestricted right of nations to political, external, and internal self-determination. Both Kolnai in his War Against the West [11], and Cassirer in his Myth of the State [3], written, respectively, shortly before and at the end of the World War Two, delivered especially clear-sighted, critical arguments on the limits of the rationality of that idea. Along with books such as Hannah Arendt's Origins of Totalitarianism[1] and Carl Joachim Friedrich and Zbigniew Brzezinski's Totalitarian Dictatorship and Autocracy [8], the arguments of Cassirer and Kolnai are also regarded as significant positions in the totalitarianism debate. Like Helmuth Plessner, who in his book Delayed Nation attempted to explain to the western reader the historical roots and philosophical background of the national-socialist ideology [20], they focused their criticism not so much on the idea of national sovereignty as such, but rather on the conditions of the possibility of specific German nationalism in its most radical form. Nevertheless, the thorough examination of Germany's rebellion against the ideals of constitutionalism, of human rights and humanism, delivered by them,

${ }^{1}$ Стаття А. Гняздовського, на прохання редактора, адаптована автором для публікації у Віснику: «Філософські науки». Інший варіант цієї статті опублікований у: Eidos: A Journal for Philosophy of Culture (Warsaw), 2018, № 3 (5), pp. 27-41. 3 огляду на сучасні соціально-політичні й культурні тенденції в Україні і світі, редакція «Вісника» вважає корисним ознайомити публіку з текстом А. Гняздовського.

(C) A. Gniazdowski, 2019 
sheds also some light on their attitude towards the idea of the nation state itself.

What allows us to compare the political philosophies of Ernst Cassirer and Aurel Kolnai in regard to the idea of national sovereignty is their focusing on the problem of the role, played in politics by emotions. Both Cassirer and Kolnai considered political phenomena as being constituted by not only rational or at least calculable mechanisms, but also affective factors, like beliefs, religion, and myth. According to Kolnai, «obviously belief is not identical with knowledge; and, since both aim at the possession of truth, we must take into account a natural and ineluctable dissension between faith and reason» $[18,270]$. Neither Cassirer, who noticed that «the preponderance of mythical thought over rational thought in some of our modem political systems is obvious» [3, 3], nor Kolnai, who stated that «with modern Fascism and particularly National Socialism the 'call for mythology' . . becomes a dominant feature», $[18,271]$ shared the optimism of the Enlightenment and its belief in the rationality of as well as progress in history. As Cassirer wrote, «scientific knowledge and technical mastery of nature daily win new and unprecedented victories. But in man's practical and social life the defeat of rational thought seems to be complete and irrevocable $[3,3] »$.

As I will argue in this paper, both Cassirer and Kolnai tended to consider nationalism with its constitutive idea of the unrestricted sovereignty of nation state in terms of the politics of «regression.» I will be using this concept as discussed in Kolnai's 1920 Psychoanalysis and Sociology, in which he presented the psychoanalytical interpretation of such political phenomena like anarchism and communism [17]. In this early work, directly influenced by the events of Bolshevist Revolution in Budapest and conceived as a study on the sociological as well as political applications of psychoanalysis, Kolnai used «regression» not in a political sense, but rather as a psychoanalytical term. Like Cassirer, who in his Myth of the State pointed out the mythic roots of the idea of a nation state (which he considered to be «invulnerable» [3, 296], Kolnai analyzed thus the regressive social and political behaviors not so much from the perspective of metaphysics of history, but rather from the phenomenology of «inner consciousness» of politics. By «regression,» he understood the «the reversion of mental life,» in some respects, to a former, or less developed, psychological state, characteristic of not only individual mental disorders, but also social psychosis like - as interpreted by Kolnai - Marxism and Leninism [17, 33]. Though Kolnai primarily applied the term to his analysis of the irrational, unconscious mechanisms of the «revolutionary consciousness,» his arguments are relevant when investigating the limitations of rationality of the idea of both sovereignties-both the «people's,» and the nation's. While taking into account also the contemporary tendency to oppose national sovereignty to the sovereignty of international law, the approach to the idea of nation state, as presented by Cassirer and Kolnai, seems to be by no means out of date.

\section{The Homeless Thought of Aurel Kolnai}

Obviously, an attempt to compare the political thought of Ernst Cassirer with that of Aurel Kolnai might raise justified objections. Cassirer and Kolnai, born, respectively, in 1874 and 1900, belonged not only to different philosophical generations, but also to different philosophical traditions. Cassirer's intellectual formation took place no later than at the end of $19^{\text {th }}$ century in a newly unified Germany. He wrote The Myth of the State as a recognized representative of Neo-Kantian School, and was well known in United States due to translations of his two books, Rousseau, Kant, Goethe, and Myth and Language [3, viii]. By contrast, The War Against the West, written by the thirty eight old Kolnai in Vienna, and published in the first year of his emigration to England, was the work of an author without an academic or even clear philosophical affiliation. In fact, in 1938 he was already the author of three books pertaining to three different theoreti- 
cal disciplines: psychoanalysis, phenomenology, and Catholic ethics ${ }^{2}$. Wickham Steed, author of the «Preface» to the first edition of The War Against the West, had nothing concrete to say about «Mr. Kolnai.» While making a note of «all the wrinkles in his English style» as well as «its little knots and knobs,» he patronisingly admitted, that even to him, despite his «bowing acquaintance with contemporary German literature,» Kolnai's book has come, «if not as a revelation in itself, at least as cumulative proof (overwhelming in its completeness) of the tendencies of such German thought as can now be printed in Germany» $[18,5]$.

Insofar as the philosophical thought of Aurel Kolnai was and remains relatively unknown, considering his political philosophy a relevant point of reference for Cassirer's criticism of the myth of the state requires some more extensive justification. Axel Honneth, editor of the volume of his selected essays Disgust, Pride, Hatred, named the afterword to that book «The Forgotten Work of Aurel Kolnai.» Honneth placed Kolnai among the most prominent «Hungarian intellectuals of Jewish descent,» and attempted to explain the weak impact of Kolnai's work on philosophy of the twentieth century. In his opinion, Kolnai's impact was far weaker than that of Karl Mannheim, Georg Lukacs, or Michael and Karl Polanyi due to the «spiritual physiognomics of his person» and the heterogeneity of his writings [5]. Honneth wrote that «Kolnai was everything but a uniform thinker, absorbed in just one thing. A philosopher by nature, he had the tendency to accept, depending on circumstances, every now and again new challenges and to make them the central subject of his work» $[5,77]$.

Indeed, along with psychoanalysis, Kolnai's fields of research before World War Two encompassed phenomenology, sociology, and political philosophy. Convinced by Scheler's criticism of Freud's concept of libido, $[23,199]$ he soon abandoned the «psychoanalytical movement» and turned towards the phenomenological one. In 1927, Kolnai published his doctoral thesis The Ethical Value and Reality, where he initiated his program of the «completion» of Scheler's material ethics of values, [4, 268] the integral part of which became the articles edited in the above-mentioned volume by Honneth. Along with one of his best-known essays, «On Disgust,» from 1929, Kolnai wrote two other papers in the 1930s: «On Hatred» and «On Pride,» where he focused on phenomenological analysis of the so called «visceral values» and «aversive emotions» [12] Concerning the «problem» of disgust- an emotion, which gained political significance in 1930s Germany-Kolnai wrote that he was «seeking to grasp the essence, the significance and the intention of disgust, and also what might be called the law of cohesion of its objectrealm» $[15,30]$. Even if Kolnai's work was not impressive to Husserl, it definitely impressed Salvador Dali, who strongly recommended this text to other surrealists in his own papers [21].

Apart from essential psychoanalytical and phenomenological insights in the nature of political emotions, gained by Kolnai due to his permanent readiness to accept new intellectual challenges, there are also other important reasons as to why his political thought remains worth reading today. One of them is that, as a Hungarian intellectual of Jewish descent, he was personally confronted with the idea of both the people's sovereignty and national sovereignty in the most dramatic way. After the liberal-democratic «Aster Revolution» in Hungary, which the then-student Kolnai greeted with enthusiasm, the next political challenges he had to accept were the Bolshevik Revolution in Budapest in 1918 and the coming thereafter right-wing Horthy's Regime. Both of these events filled Kolnai with disgust and motivated him to leave Hungary and to study in Vienna. After Anschluss, Kolnai emigrated from Austria, and from 1938 onwards lived in France, England, United States, Canada and, from 1955 until his death, in England again.

${ }^{2}$ Apart from Psychoanalysis and Sociology and numerous articles concerning different ethical and political topics, he published Der ethische Wert und die Wirklichkeit, (Freiburg, 1927) and Sexualethik. Sinn und Grundlagen der Geschlechtsmoral, (Paderborn, 1930). 
Kolnai's own statement of nationality, forced by the sovereign, internal policy of German states in regard to the nationality of its citizens, expressed: «until 1929, Hungarian; 1929-1938, Austrian; thereafter stateless; 1951-1962, Canadian; thereafter British [14]».

Among the reasons why the work of Aurel Kolnai remains forgotten today, Honneth also numbered political restlessness and elasticity, allegedly corresponding to the changeable character of his philosophical productivity. As he noticed, having «grown up in Budapest as a Jew, in exile in Vienna Kolnai quickly converted to Catholicism, where he initially joined the Catholic left, and eventually found his political homeland in Christian conservatism [5, 77]». As his first conservative «ID» Honneth read the 1929 book Sexual Ethics, about the meaning and foundations of gender morality, which he interpreted as Kolnai's ideological approach to human sexuality, caused by his Roman Catholic conversion $[5,77]$. The question of legitimacy of that interpretation as well as that of internal cohesion of Kolnai's early writings with his work as a whole requires a separate analysis. There is no doubt, indeed, that in the time of struggle between the idea of liberal democracy and that of a totalitarian state, which determined the political face of twentieth century, the catholicized conservative political philosophy developed by Kolnai after World War Two turned out to be for him to the same extent the spiritual homeland, as the way to also spiritual exile and homelessness.

Perhaps, however, it is worth taking a closer look, whether the reasons of the weak impact of Kolnai's work on philosophy of twentieth century are not the same as those which make his political thought the relevant point of reference for the interpretation of political meaning of Cassirer's Myth of the State.

\section{Psychoanalysis and Politics}

In spite of their awareness of the power of mythical thought and their pessimistic views on the course of history, both Cassirer and Kolnai believed in the possibility of the «struggle against myth» and in the not only philosophical, but also political, significance of its theory. At first look, their theoretical answers to the «call of mythology», ringing out, according to them, in the twentieth century, seem to have little in common. Unlike Kolnai, Cassirer expressed skepticism with regard to the theoretical capacity of psychoanalysis for overcoming of the power of myth. Even though he considered the general theory of emotions developed by Freud with some favor, his reading of the psychoanalytical interpretation of myth, discussed in the chapter «Totem and Taboo,» was critical. As he wrote, «it is not a very satisfactory explanation of a fact that has put its indelible mark upon the whole life of mankind to reduce it to a special and single motive. Man's psychic and cultural life is not made of such simple and homogeneous stuff» $[3,35]$. While considering psychoanalysis itself for being in that manner a kind of mythology, Cassirer predicted, that «after a few decades, the sex myths will share the fate of the solar or lunar myths» [3, 35].

By contrast, as a student of Sigmund Freud's close friend and collaborator, who founded the Budapest School of Psychoanalysis, [19] Kolnai was, in his first book, totally enthusiastic about the possibility of psychoanalytical theory of politics. He not only preceded the Frankfurt School in applying the results of psychoanalysis to social theory, but worked in a way converse to the Frankfurt School's methods. As he wrote in article «The Humanist Significance of Psychoanalysis,» «one can easily get an idea, that psychoanalysis performs in regard to individual psyche the same work as Marxism in regard to the social structure and that it could be taken therefore as its continuator and co-fighter» $[9,355]$. However, Kolnai formulated a list of arguments against the idea of Marxism and psychoanalysis as co-operative areas of thought. As he stated, even though Freud's theory, not unlike that of Marx, «has been led to recognize the existence of an intimate mutual determinism between individual and society» $[17,10]$, the emancipated spirit of psychoanalysis enabled it to penetrate «the barriers erected mainly for affective reasons 
between the individual mind and the community», $[17,12]$ much more effectively than Marxist materialist-economic dogmatism.

According to Kolnai, the sociological as well as political implications of psychoanalysis, free of any metaphysics of history, consisted first of all in everything but messianic, revolutionary practice. As he wrote, «the original aim of psychoanalysis is extremely simple; the cure of the patient. ... It aims at securing for the individual a better balance, at bringing about a better adaptation to the environment, at establishing a higher rationality, and producing a more perfect harmony» $[17,14]$. While pointing out that «this is precisely the aim which politics should pursue in relation to the community,» Kolnai emphasized, that «these two aims cannot remain independent» $[17,15]$. As he wrote, «there are no men without institutions, and there are no institutions without men. The observer may be especially concerned either with men or with institutions, but he must not fail to take the other element into the reckoning» $[17,15]$. Unlike advocates of the Frankfurt School, Kolnai argued that psychoanalysis is closer to a physiosocratic-individualistic approach to society in its socio-political implications than Marxist social criticism, which is one-sidedly oriented on abolishing the social institution of property $[17,136]$. In his first book, Kolnai already recognized not Marxism, but the theory of social solidarity as developed by Emile Durkheim. This rather conservatively oriented sociological trendwas from the very beginning in harmony with Kolnai's own psychoanalytic thought.

To Kolnai, Durkheim's most important distinction was that between the «mechanic solidarity,» ruling in the societies, based on religion and tradition, and the «organic solidarity,» specific to the complex social organisms and founded on the division of labor. According to Durkheim, mechanic solidarity, which characterizes the primitive societies, was its lower form to the extent that it was associated with a similarity of their members and based upon the identity of their ideologies. Durkheim's distinction allowed Kolnai to give the above-mentioned, psychoanalytical category of «regression» sociological significance. Insofar as psychoanalysis teaches us that «mental disorders are disturbances of the adaptation to the extant form of society,» which result in «regressions to lower stages», [17, 26] psychoanalytic research on the mechanisms of regression could contribute to research into both the evolution and pathology of development of the society and culture. In Kolnai's opinion, Durkheim's theory of social solidarity, based mainly upon juristic philosophy and focused on the social institution, could be aided by psychoanalysis. Psychoanalysis could have furnished an important aid by a comparison between the world of individual thought and the world of social thought and, in this way, fill an outspoken gap within that theory.

According to young Kolnai, psychoanalysis had nothing in common with any kind of «mythology.» Unlike for Cassirer, the humanistic and social emancipatory significance of Freud's theory of emotions consisted for him in acting as a «midwife» to the culture of organic solidarity, and so serve as an indispensable foundation of the complex modern society. Psychoanalytic concepts such as ambivalence, psychical conflict, repression, projection, or symbolization denoted for Kolnai, on the one hand, psychical phenomena of social origin, which determine, on the other hand, the social institutions themselves. Inherent in Freud's theory was, in his opinion, by no means reducing man's cultural and political life to the human sexuality. He regarded as one of the first and most important acquisitions of psychoanalysis the way in which it paid due attention to unconscious mental phenomena as well as the method which it developed in order to achieve a real knowledge of the unconscious. In his interpretation, its humanistic, rational, and political meaning was not incontrollable emphasizing with the unconscious and immersing in it, but broadening, brightening and strengthening of the conscious. For him, it depended upon «getting to know the unconscious by means of conscious and appropriate influencing the life shaped by drives and founded in the unconscious» $[9,350]$. 
From the psychoanalytic perspective, Kolnai wrote, the content of the unconscious consists of wishes the realization of which, and even the expression of which, is forbidden by society. Its social meaning he perceived in fact, that within Freud's theory the unconscious as opposed to the conscious, which is what can be adequately incorporated in a system of extant social conventions, is by definition non-social. He wrote, «there is a striking resemblance between the individual and mass manifestations of the unconscious,» and the purpose of psychoanalysis was, according to Kolnai, to throw light on the unconscious elements of both the psyche and society, to place them at the disposal of the conscious and to replace them with a social equivalent $[17,54]$. Freud's theory of emotions, Kolnai stated in the article «The Humanist Significance of Psychoanalysis,» is nothing but «the organic efflorescence of Western civilization on its way to mastering the whole internal as well as external world by consciousness» [9, 350].

\section{The Origins of Political Mythologies}

If Kolnai, in Psychoanalysis and Sociology, but also in The War Against the West, saw the expression of the contemporary power of mythical thought in the «doping the common man» with the «supra-rational» myth of revolution, $[18,58]$ Cassirer focused in his political writings on the myth of the «Power State.» In The Myth of the State, where he pointed out that the power of this myth in his time started to rise anew and to pervade the whole of man's cultural and social life [3], he did not limit himself to mere political phenomenology. The two first parts of this book, written during the Normandy Landings and the campaign of the Allies in Europe, were dedicated to answering the question «What is Myth?» and to reconstructing «The Struggle against Myth in the History of Political Theory» from Plato to the philosophy of the Enlightenment. Only in the last part, «The Myth of the Twentieth Century,» (whose title refers to a work by Alfred Rosenberg, a Nazi Party ideologue) [22], did Cassirer analyze the more immediate historical context of national-socialist ideology. This context was, in his opinion, Thomas Carlyle's lectures on hero worship, the racial theories of Arthur de Gobineau, and Hegel's hypostatizing the state. In his comment on Hegel's passage which reads «men are as foolish as to forget . . . in their enthusiasm for liberty of conscience and political freedom, the truth which lies in power,» Cassirer wrote: «these words written in 1801, about 150 years ago, contain the clearest and most ruthless program of fascism that has ever been propounded by any political or philosophic writer» $[3,267]$.

Cassirer justified his historical-political approach to the myth of the state-and its irrational «reason»-with the statement that a philosophy of political myth can do us an «important service» $[3,267]$. He wrote that «we should carefully study the origin, the structure, the methods, and the technique of the political myths,» since «we should see the adversary face to face in order to know how to combat him» [3,3]. Accordingly, Cassirer searched for the deepest origins of political mythologies not so much in explicit philosophical thought itself, but already in the most primitive rituals and ceremonies, which he considered as even «deeper and much more perdurable element in man's religious life than myth» $[3,24]$. The function of mythology that was rooted in social ritual showed a «unity of feeling» that both myth and religion gave to humans. Like art, which, as Cassirer wrote, «opens to us the universe of 'living forms,'« and like science, which «shows us a universe of laws and principles,» myth and religion «begin with the awareness of the universality and fundamental identity of life» $[3,37]$.

As Cassirer wrote in An Essay on Man, «in the history of mankind the state, in its present form, is a late product of civilizing process», $[2,87]$ the roots of the myth of the state, like those of other myths, were identified by him to some extent with roots of being human. He saw myth rooted in the symbolic, constitutive for human beings' expressions of emotions as opposed to their merely physical expressions, which was specific for animals. Cassirer considered such a symbolic expressions to be a «common denominator» in all cultural activities of man: «in 
myth and poetry, in language, in art, in religion and in science», [3, 45] which have as their task the objectification of different modes of human emotions. Among other symbolic expressions of emotions, he acknowledged in this way a certain «objective» aspect and a definite objective function of political myths. Like linguistic symbolism, which leads to an objectification of sense-impressions, the symbolism of those myths consisted for Cassirer of an «objectification of feelings» or, strictly speaking, the way they determined «man's social experience» [3, 47]. Even if he declared in An Essay on Man, that «the state, however important, is not all. It cannot express or absorb all the other activities of man», $[2,88]$ he regarded it as a mode of cultural objectification, as a specific «symbolic form,» and not as a mere «hypostasis».

Cassirer also considered the origins of his contemporary, political mythology, not just lost to the more or less recent past, but part of human nature itself; because of this, he stated that «a myth is in a sense invulnerable» $[3,47]$. As he wrote, «this description of the role of magic and mythology in primitive society applies equally well to highly advanced stages of man's political life. In desperate situations man will always have recourse to desperate means - and our present-day political myths have been such desperate means» $[3,279]$. He regarded myth as «impervious to rational arguments,» and admitted that «it is beyond the power of philosophy to destroy the political myths» $[3,296]$. That «the most important and the most alarming feature in the development of modern political thought is the appearance of a new power: the power of mythical thought», $[3,3]$ might thus, according to him, have been expected. When asking after how it was possible that, after a short and violent struggle, mythical thought seemed to win a clear and definitive victory over rational and scientific thought, he was in fact asking about the conditions of possibility of that «short and violent struggle» itself.

Insofar as Cassirer considered the history of political theory to be the history of the «struggle against myth,» he identified it, like Kolnai did, in regard to the history of Western civilization, with «mastering» the world of political myths by consciousness. In Cassirer's interpretation, the «civilizing process,» the part of which was building more and more complex or «advanced» human societies and symbolic expressions of their political life, also consisted in the transition from Durkheim's «mechanic solidarity» to its «organic,» conscious form. As he wrote, «man, like the animals, submits to the rules of society but, in addition, he has an active share in bringing about and an active power to change, the forms of human life» [2, 280]. According to Cassirer, «human culture taken as a whole,» that is including also political culture, «may be described as the process of man's progressive self-liberation» [2, 286].

In spite of that, the belief in the continuing «progress» in history and allegedly inherent to the Western civilization rationality Cassirer considered to be an expression of mythical thought, insofar as he felt himself «inclined to favor» in his theory of symbolic forms the thesis of «the discontinuity and radical heterogeneity of human culture» [2, 286]. According to him, the sex myths of psychoanalysis and the economic myths of Marxism, as reducing human culture to a homogeneous stuff, did not comply with requirements of the rational philosophy of culture because of a «multiplicity and multiformity of its constituent parts» [2, 279]. The human culture, that is also Western civilization, formed for Cassirer an «organic,» «functional» unity as a «dialectic unity, a coexistence of contraries» $[2,279]$. As he wrote, «if there is an equipoise in human culture it can only be described as a dynamic, not a static equilibrium: it is the result of a struggle between opposing forces» [2, 279].

Cassirer tended - not unlike Kolnai with his «conservative» interpretation of the humanistic meaning of psychoanalysis - to regard the struggle against myth in the history of political theory, as the expression of the same dynamics. He attempted to answer the question of «why humanity, instead of entering a truly human state, is sinking into a new kind of barbarism» 
[7, xiv] (also posed by Horkheimer and Adorno in the Dialectic of Enlightenment), by using a simile borrowed from mythology. Cassirer admitted, that, on the one hand, the world of human culture, as described by means of a Babylonian legend, could not have arisen «until the darkness of myth was fought and overcome» [3, 298]. On the other hand, he pointed out, that after that short and violent struggle the mythical monsters were not entirely destroyed. They were used for the creation of a new universe, and they still survive in this universe. The powers of myth were checked and subdued by superior forces. As long as these forces, intellectual, ethical, and artistic, are in full strength, myth is tamed and subdued. But once they begin to lose their strength chaos is come again. Mythical thought then starts to rise anew and to pervade the whole of man's cultural and social life [3, 298].

\section{"Living on Volcanic Soil»}

Both Kolnai and Cassirer thus interpreted the revival of mythical thought in modern political philosophy as a kind of «regression.» Their thought especially pertains to the myth of the «nation» and the national right to political sovereignty, restricted by nothing but its internal reason. They both considered this myth of national sovereignty to be an expression of the dialectic, which consisted in «relapsing» of the Enlightenment into mythology [7, xvi]. Like Kolnai in The War against the West, Cassirer, too, could have written: naturally I am aware that a universally fixed type of «primitive tribe» does not exist, still less do I mean to suggest that the present rulers of the German nation consciously wish to reduce it to such a social form. I merely wish to point out that the Nazi attitude, when contrasted with more civilized and complex societies, is somehow strikingly reminiscent of certain fundamental features of such tribes, and that the mental revolution accompanying National Socialism reveals, in its conception of the ultimate problems of the value of man and his subjection to power, a mysterious reversion to prototypes of that kind [18, 32].

Cassirer saw the historical origins of the mythology of national sovereignty and unrestricted right of nation to political self-determination in the Romantic era. In reference to Goethe's dramatic scene from Faust in which the witch waits for the drink that will give back her youth, Cassirer stated, that «the Romantic philosophers and poets were the first who had drunk from the magic cup of myth» $[3,5]$. As he wrote, «Romanticism launched a violent attack against the theory of natural rights. The romantic writers and philosophers spoke as resolute 'spiritualists.' But it was precisely this metaphysical spiritualism that paved the way for the most uncouth and uncompromising materialism in political life» [3, 141]. Cassirer regarded the romantics' new interest in history and myth to be one of the conditions of the possibility that «nationalism had, since the beginning of the nineteenth century, become the strongest impulse and driving force of political and social life» [3, 123]. In so far as they pushed back against Enlightenment ideals of rationality and instead «loved the past for the past's sake» and treated it as «not only a fact but also one of the highest ideals,» the romantics, according to Cassirer, paved the way for the assumption that «human culture is not an offspring of free and conscious human activities. It originates in a 'higher necessity.' This necessity is a metaphysical one; it is the natural spirit which works and creates unconsciously» $[3,182]$.

Nevertheless, German Romanticism was for Cassirer the necessary, but by no means sufficient, condition of possibility of Rosenberg's «myth of twentieth century.» Cassirer pointed out that it would be a mistake to hold the romantic spirit responsible for the later development of the idea of national sovereignty. He emphasized that «the 'totalitarian' view of the romantic writers was, in its origin and meaning, a cultural not a political view. The universe they were longing for was a universe of human culture. They never meant to politicize but to 'poeticize' the world» $[3,184]$. While maintaining that romantic nationalism was «a product of love not, as so many later forms of nationalism, of hatred» $[3,186]$, Cassirer saw more powerful 
external sources as responsible for imperialistic German nationalism. As he wrote, «in the age of the Napoleonic Wars the founders and pioneers of German romanticism began to doubt their own ideal of 'poeticizing' political life. They became convinced that, at least in this field, a more 'realistic' attitude was imperative and indispensable» [3, 186].

In his interpretation of Carlyle's lectures, Gobineau's Essai sur l'inegalite des races humaines, and Hegel's political theory, Cassirer also challenged their direct influence on the ideology of national socialism. Cassirer presented a «new technique» of political myth as the last, decisive factor responsible for the development of national sovereignty unrestricted by the rule of law. As opposed to traditional political mythology, described as the result of an unconscious activity and as a free product of imagination, Cassirer wrote, «the new political myths do not grow up freely; they are not wild fruits of an exuberant imagination. They are artificial things fabricated by very skillful and cunning artisans» $[3,282]$. The first step in developing a new technique of myth was a change in the function of language. That change consisted in the «magic word» taking precedence over the semantic word. He confided: «If nowadays I happen to read a German book, published in these last ten years, not a political but a theoretical book, a work dealing with philosophical, historical, or economic problems - I find to my amazement that I no longer understand the German language» [3, 283].

Cassirer's interpretation of the sources of his contemporary preponderance of the mythology of German «Power State» over rational political thought, which would aim at subordinating the German political life to the «universe of laws and principles,» turns out to be an ambiguous one. On the one hand, considered from the point of view of his philosophy of culture, German nationalism seems to be for him nothing but the expression of the inherent, above-mentioned dynamics or dialectics of culture taken as a whole. As Cassirer wrote in An Essay on Man, «in all human activities we find a fundamental polarity, which may be described in various ways... Now the one factor, now the other, seems to preponderate» [2, 281]. Like Kolnai, who in reference to Freud's theory of emotions pointed out at the persistent conflict between «regressive libido capital» of mass movements and «a modified, sublimated, non-despotic, democratic form, a form which involves no oppression, but supplies rational inhibition or guidance» [17, 101-113], Cassirer considered the political expression of that polarity, that «in politics we are always living on volcanic soil. We must be prepared for abrupt convulsions and eruptions. In all critical moments of man's social life, the rational forces that resist the rise of the old mythical conceptions are no longer sure of themselves» $[3,5]$.

On the other hand, however, while taking into account the «artificiality» of the modern political myths and their «new technique,» Cassirer seemed to recognize the conscious character of modern German nationalism as an «active power» to change the extant form of German political life. Insofar as he meant by the inherent dialectics of culture taken as a whole «a tension between stabilization and evolution, between a tendency that leads to fixed and stable forms of life and another tendency to break up this rigid scheme» [2, 281], it remains ambiguous whether Cassirer saw in the idea of German Power State an expression of the tendency, which «seeks to preserve old forms» or the tendency, which «strives to produce new ones» $[2,281]$. There is no doubt, indeed, that Cassirer by all his admiration for the «new and unprecedented victories,» which are daily won by the «scientific knowledge and technical mastery of nature,» was in The Myth of the State extremely critical against «skillful and cunning artisans» like Alfred Rosenberg and the new political myths they produced. Nevertheless, if he considered the defeat of rational political thought in him contemporary Germany to be nothing but the preponderance of mythical thought as an invulnerable cultural factor «impervious to rational arguments,» it is not clear, how his philosophy, in a struggle against it, can do for us an «important service.» 


\section{The Conservative Politics of Progress}

It seems, that due to an ambiguous political meaning of Cassirer's Myth of the State, the political philosophy of Aurel Kolnai can serve as an above-mentioned «completion» of not only Scheler's material ethics of values, but also Cassirer's philosophy of culture. It is noteworthy that in An Essay on Man Cassirer did not list politics among other «symbolic forms» like myth, language, art, religion, history and science, and he did not analyze its «specific character and structure» $[2,281]$. In discussing the question of to what extent the «state» and the «nation» are to be regarded from the perspective of Cassirer's philosophy as political myths, and to which extent they can be interpreted as rational political ideas, Kolnai's politically outspoken philosophy can be, therefore, an important point of reference. Both his psychoanalytical interpretation of anarchism and communism, and his phenomenological research in the «essence, the significance and the intention» of National Socialism are able to shed some light especially on the question of the limits of the rationality of these ideas.

It seems that in spite of the ambiguity of Cassirer's political attitude in The Myth of the State, he felt himself inclined to admit, like Kolnai in his early work in regard to psychoanalysis, that the place of his philosophy of culture in the «struggle of the great powers» is by the side of «liberal socialism» $[17,82]$. However, the stress he put on the invulnerability of myth and the heterogeneity of culture, that is on the fact that «the various powers of man,» which «tend in different directions and obey different principles... cannot be reduced to a common denominator» [2, 286], allows us to place Cassirer's political attitude to the same extent by the side of liberal conservatism of Burke's and Tocqueville's style, ascribed to Kolnai since his Christian conversion. On the one hand, Cassirer pointed out that «in myth and in primitive religion the tendency to stabilization is so strong that it entirely outweighs the opposite pole. These two cultural phenomena seem to be the most conservative powers in human life» $[2,281]$. On the other hand, he admitted: «even language is one of the firmest conservative powers in human culture. Without this conservatism it could not fulfil its principal task, communication» [2, 282].

Kolnais' paper «The Content of Politics» can be read as a completion of Cassirer's philosophy of symbolic forms, especially in regard to the question of the specific character and structure of the political. In his article, the title of which referred to Carl Schmitt's most discussed book, The Concept of the Political, Kolnai attempted to reveal the irrationality of Schmitt's theory. He placed his anti-positivist and anti-liberal theory of state in the tradition of political thinking, initiated by the philosophies of Nietzsche, Klages, Bergson, Sorel, Pareto, Spengler, Heidegger and, to some extent, by the political philosophy of Scheler [13]. According to Kolnai, the irrationalism of these philosophies consisted of interpreting life as an end in itself and not as being determinable by rational goals and ethical or logical values. He especially opposed Carl Schmitt's blind decisionism and allegedly purely formal difference between friend and enemy, regarded by Schmitt as the foundation of the concept of the political. Kolnai's opposition to his decisionism focused on the idea of the theory of state as a theory of political order. The proper subject of such a theory had to be, according to Kolnai, the afore-mentioned «content» of politics, that is «the question, which way the state is governed and which way it should be, to which extent the rule and inequality are inevitable, which material qualifications or areas of values are they connected with, to which extent should they be concentrated and to which extend divided, etc» $[13,23]$.

There is no doubt that Kolnai's extensive study The War against the West, where he delivered one of the first critical analyses of the «essence» of Nazism as a political phenomenon, can be regarded as a completion of Cassirer's The Myth of the State. As one of the decisive factors of its rise to power he regarded in his book the «self-destruction of liberal idealism» and stressed this 
time also the role played in that process by psychoanalysis. He pointed out, that to the extent, that «Klages is not far from Freud», the psychoanalytical «glorification of urges and instincts, of complexes and natural desires which attributes overwhelming power to sensual lust and unconscious impulse», $[18,15]$ was an important aspect of that self-destruction. Even though Kolnai had no chance to refer in his study to Cassirer as a political thinker, he, like Cassirer, treated the rising German Power State and rising German national revolution in terms of the revival of mythical thought. He interpreted that revival as an answer to the «call for mythology,» which indicated, according to him «the will to break the spiritual backbone of man, to supersede personality, with its consciousness of eternal relations, by a flabby vital stock of ethnic unity, to pull down the last strongholds of the mind in which human freedom and dignity could entrench themselves against the totalitarian encroachment of an insane and godless tyranny» [18, 272-273].

The question of affinities between political thought Cassirer and liberal conservatism of late Kolnai - eminiscent of Eric Voegelin or Leo Strauss's works - would require a separate analysis. Kolnai's emphasis on the political significance of such social phenomena as hierarchy and privilege, anathematized in the modern political world and banned from the public discourse, made his philosophy disreputable to the representatives of not only fascist reactionaries, but also socialist and liberal-democratic, and the «progressive» political camp. In so far as he regarded privilege and hierarchy, in reference to Scheler's ethics, paradoxically, as a «rampart of liberty» and a necessary counterbalance to the «totalitarian democracy» [16, 47], his political attitude in the postwar time could be, paradoxically, described as a program of the conservative politics of progress. While considering the idea of radical sovereignty of the people, constitutive for the totalitarian form of democracy, to be a threat to the modern political world as a whole, Kolnai wrote in one of his postwar writings:

what we have in mind is not, of course, a proposal to substitute for Western Democracy along with its ideological biases, a fancy system of Conservative Constitutionalism, nor a return to this or that specified stage of the past, but a suggestion to displace the spiritual stress from the 'common man' aspect of democracy to its aspect of constitutionalism and of moral continuity with the high tradition of Antiquity, Christendom and the half-surviving Liberal cultures of yesterday $[11,273]$.

\section{Bibliography:}

1. Arendt Hannah, Origins of Totalitarianism (New York: Harcourt, 1951).

2. Cassirer Ernst, An Essay on Man. An Introduction to a Philosophy of Human Culture, Yale University Press, 1944).

3. Cassirer Ernst, The Myth of the State (New Haven: Publisher, 1946).

4. Dunlop Francis, Kolnai's Dissertation Der ethische Wert und die Wirklichkeit: A «Completion» of Scheler's Value-Ethics, in Zoltan Balacs and Francis Dunlop, Exploring the World of Human Practice: Readings in and about the Philosophy of Aurel Kolnai (New York, 2004).

5. Honneth Axel. «Phänomenologie des Bösen. Das vergessene Werk von Aurel Kolnai» published as «Afterword» to A. Kolnai,, Frankfurt am Main 2007.

6. Honneth Axel, Die Phänomenologie des Bösen. Das vergessene Werk von Aurel Kolnai» published as «Afterword» to A. Kolnai,, Frankfurt am Main 2007.

7. Honneth Axel, Vivisektionen eines Zeitalters. Porträts zur Ideengeschichte des 20. Jahrhunderts, Berlin 2014, pp. 76-77.

8. Horkheimer Max, Adorno Theodor, Dialectic of Enlightenment: Philosophical Fragments, trans. By Edmund Jephcott (Stanford: CA, Stanford University Press, 2002).

9. Joachim Carl. Friedrich and Zbigniew Brzezinski, Totalitarian Dictatorship and Autocracy (City of Publication: Harvard University Press, 1956). 
10. Kolnai Aurel, «Die geistesgeschichtliche Bedeutung der Psychoanalyse,» Internationale Zeitschrift für Psychoanalyse 9.3 (1923): 355.

11. Kolnai Aurel, «Max Scheler's Kritik und Würdigung der Freudschen Libidolehre,» Imago. Zeitschrift für Anwendung der Psychoanalyse an Geisteswissenschaften, (1925):135-146.

12. Kolnai Aurel, «The Meaning of the Common Man,» Thomist (1949).

13. Kolnai Aurel, «The Standard Modes of Aversion: Fear, Disgust and Hatred, Mind, 107(1998), s. 581-595.

14. Kolnai Aurel, Der Inhalt der Politik, «Zeitschrift für die gesamte Staatswissenschaft», Bd. 94, H. 1. (1933), s. 1-38.

15. Kolnai Aurel, Ethics, Value \& Reality (London and New York, 2008).

16. Kolnai Aurel, On Disgust (Chicago and La Salle, 2004).

17. Kolnai Aurel, Privilege and Liberty and other Essays in Political Philosophy (Lanham, 1999).

18. Kolnai Aurel, Psychoanalyse und Soziologie. Zur Psychologie von Masse und Gesellschaft (Leipzig/Wien/Zürich, 1920). The first English edition of this text is Psychoanalysis and Sociology, trans. Eden and Cedar Paul (New York: Harcourt, 1922).

19. Kolnai Aurel, The War Against the West (New York: Publisher, 1938).

20. Mészáros J., Ferenczi and Beyond. Exile of the Budapest School and Solidarity in the Psychoanalytic Movement during the Nazi Years (London, 2014).

21. Plessner Helmuth, Verspätete Nation. Über die politische Verführbarkeit bürgerlichen Geistes (Stuttgart, 1959). (First published as Schicksal deutschen Geistes im Ausgang seiner bürgerlichen Epoche, Zürich, 1935).

22. Radford Robert, "Aurel Kolnai's 'Disgust': a Source in the Art and Writing of Salvador Dali,» in Zoltan Balacs and Francis Dunlop, Exploring the World of Human Practice, (City: Publisher, year), s. 327-333.

23. Rosenberg Alfred, The Mythos des 20. Jahrhunderts, (München, 1934).

24. Scheler Max, The Nature of Sympathy, trans. by P. Heath (New Brunswick, 2008).

\title{
ПОЛІТИКА РЕГРЕСІЇ: ІДЕЯ НАЦІОНАЛЬНОЇ ДЕРЖАВИ У ПОГЛЯДАХ ЕРНСТА КАССІРЕРА ТА АУРЕЛА КОЛНАЯ
}

\author{
Анджей Гняздовський \\ Польська Академія Наук, Інститут філософії та сочиілогії, \\ вул. Новий Світ, 72, 00330 Варшава, Польща, \\ agniazdo@ifispan.waw.pl
}

\begin{abstract}
Мета статті полягає у проведенні компаративного дослідження підходів Е. Кассірера та А. Колная щодо тлумачення ідеї національної держави у радикальному іiї розумінні. Це стосується ототожнення національної суверенності з необмеженим правом народу як до зовнішнього, так внутрішнього політичного самоокреслення. Особлива увага в запропонованому аналізі приділяється діагнозу причин виникнення специфічної форми німецького націоналізму (з подальшою його критикою), який представлений, з одного боку, Е. Кассірером у праці «Міт держави» (1946), та грунтовним дослідженням А. Колная за назвою «Війна проти Заходу» (1938), - з іншого.

Докладно аналізується філософський підхід А. Колная - одного з впливових i, на жаль, забутих представників будапештської школи психоаналізу й феноменологічного напряму у філософії. У статті обгрунтовано наукову доречність порівнювати критику національного соціалізму А. Колная, розвинуту ним у 1930-х роках, із критикою міту держави, запропонованою Е. Кассірером, як визначним представником неокантіанства. Однією із підстав співставлення їхніх позицій $є$ те, що обидва вчені підкреслювали суттєве значення ролі емоцій у соціально-політичному житті. На думку автора статті, ці дослідники інтерпретували політичні феномени як такі, що конституюються у результаті
\end{abstract}


впливу не лише раціональних механізмів, але також таких афективних чинників, як вірування, релігія або міт.

Обгрунтовано, що і Е. Кассірер, і А. Колнай схилялися розглядати явище націоналізму у категоріях політики «регресії». Висувається припущення, що подібний підхід започаткував саме А. Колнай у своїй першій книжці «Психоаналіз та соціологія» (1921). У ній він запропонував психоаналітичне визначення регресії як різновиду скерування психічного життя до попереднього або менш розвинутого психологічного стану. Покликаючись на концепцію 3. Фройда, викладену у розвідці «Тотем і табу», А. Колнай доводив у своєму дослідженні, що під таким кутом бачення механізм регресії стає характерним не лише для індивідуальних психічних хвороб, але також і масових психозів, які проілюстрував явищами фашизму та комунізму.

Продемонстровано, що Е. Кассірер і А. Колнай, подібно, як і М. Горкгаймер і Т. Адорно у книзі «Діалектика Просвітництва», трактували розквіт мітичного мислення у політичній філософії як вияв діалектичного розуму, іманентного для західної культури. Діалектичність, в свою чергу, проявляється у парадоксальній тенденції просвітницького раціоналізму приховано схилятися до мітології.

У статті підкреслюється, що Е. Кассірер і А. Колнай, на відміну від згаданих представників Франкфуртської школи, не поділяли віри останніх у винятково емансипаційну функцію мислення. Єдино можливий, хай навіть і обмежений, «поступ» в історії згадані дослідники вбачали у протистоянні політичним мітологіям, як формам політичної регресії, що розгортається на шляху наукової, економічної і мистецької активності. Тому їхній підхід запропоновано визначати як приклад парадоксальної «консервативної політики поступу».

У підсумку доводиться, що компаративний аналіз соціально-політичної філософії Е. Кассірера і А. Колная є евристичним щодо його застосовування у контексті сучасних тенденцій опозиційного порівняння «необмеженого національного суверенітету» і суверенітету міжнародного права. Обгрунтовано, що методологія аналізу названими мислителями ідеї національної держави не втрачає актуальності в наш час.

Ключові слова: національна держава, регресія, мітологія, поступ, політична незалежність. 